


\section{PUBLICATIONS OF THE INSTITUTE OF BUSINESS AND ECONOMIC RESEARCH}

Recent publications in this series:

A Theory of Accounting to Investors

by George J. Staubus (I96I)

Organization, Automation, and Society by Robert A. Brady (I96I)

Housing Policy-The Search for Solutions by Paul F. Wendt (1962)

Competition, Regulation, and the Public

INTEREST IN NONLIFE INSURANCE

by Roy J. Hensley (1962)

Public Enterprise Economics and Transport Problems

by Tillo E. Kuhn (1962)

Asset Prices in Economic Analysis

by Samuel B. Chase, Jr. (1963)

The Six-Legged Dog: Mattei and ENI-A STUdy IN Power by Dow Votaw (1964) 


\title{
INTER-ECONOMY COMPARISONS
}

\author{
A CASE STUDY
}





\section{Publications of the}

Institute of Business and Economic Research

University of California

\section{INTER-ECONOMY \\ COMPARISONS \\ A CASE STUDY}

A GOMPARATIVE STUDY OF

INDUSTRIAL DEVELOPMENT,

CURRENGY DEVALUATION,

AND INFLATION

by Leonard A. Doyle

UNIVERSITY OF CALIFORNIA PRESS 1965 BERKELEY AND LOS ANGELES 


\title{
University of California Press \\ Berkeley and Los Angeles
}

\author{
Cambridge University Press \\ London, England
}

A research study under coöperative arrangements among the following:

In the Republic of Indonesia: P. N. Pabrik Semen "Gresik," Surabaja, East Java; Bank Pembangunan Indonesia; Department of Basic Industry and Mining; State Accounting Office, Department of Finance

In the United States of America: Institute of Business and Economic Research, University of California, Berkeley, under a grant from the Rockefeller Foundation; The Permanente Cement Corporation, Kaiser Center, Oakland, California

(C) 1965 by The Regents of the University of California

Library of Congress Catalog Card Number: 65-12925 Printed in the United States of America 


\title{
Institute of Business and Economic Research \\ University of California, Berkeley
}

\author{
Hyman P. Minsky, Chairman \\ K. Roland A. Artle \\ James M. Carman \\ John W. Cowee \\ John M. Letiche \\ Tibor Scitovsky \\ Joseph W. Garbarino, Director (on leave) \\ Lee E. Preston, Acting Director
}

The opinions expressed in this study are those of the author. The functions of the Institute of Business and Economic Research are confined to facilitating the prosecution of independent scholarly research by members of the faculty. 
